\title{
The effects of cooperative learning on reading comprehension
}

\section{The Effects of Cooperative Learning on Reading Comprehension}

Noemi Mercedes Remache Carrillo. ${ }^{1}$, Mariela Germania Pilco Labre. ${ }^{2}$, Viviana Vanessa Yanez Valle. ${ }^{3}$

\begin{abstract}
.
This study aimed to determine the influence of cooperative learning in reading comprehension of high school students at Unidad Educativa "Riobamba" during 2017-2018 school period. For the assessment of the validity and effectiveness of this research, a pre-test and a post-test were applied based on the Cambridge PET (Preliminary English Test) exam, reading section. That exam was composed of two parts: the first was carried out through a cooperative work in pairs and the second part, taking into consideration the cooperative work in groups of four students. A didactic guide for the teacher was designed and applied in the classroom. After that, the analysis of data was made before and after applying the intervention. The teacher's guide was designed to put cooperative learning strategies such as jig-saw, think-pair-share, and reciprocal questioning into action. Three stages of reading were used namely before reading, during reading, and after reading. After the implementation of the proposal, the data analysis was performed using the T-student mathematical test. It is concluded that the students improved their reading comprehension through cooperative work in pairs and in groups as well. It was recommended that teachers practice cooperative learning in the classroom to improve students' reading comprehension in order to optimize their development in English language learning.
\end{abstract}

${ }^{1}$ Escuela Superior Politécnica de Chimborazo, Centro de Idiomas, Riobamba, Ecuador, noemi.carrillo@espoch.edu.ec

${ }^{2}$ Unidad Educativa Riobamba, Riobamba, Ecuador, marielapilco@yahoo.com.

${ }^{3}$ Escuela Superior Politécnica de Chimborazo, Centro de Idiomas, Riobamba, Ecuador, viviana.yanez@espoch.edu.ec; 
Keywords: Cooperative learning, effects, reading comprehension, strategies

Introduction.

Reading comprehension is an important issue in English classes. However, it is not seemed as completely developed for students. Therefore, it is important to analyze what happens in the world, in Ecuador, and at Unidad Educativa "Riobamba".

Marzbana and Alinejadb (2014) argue that reading is a paramount skill in English language as well as listening, speaking, and writing. It plays a fundamental role in obtaining knowledge from original sources. In fact, learning to read is essential aspect children achieve in schools as support for future academic aims (Stevens, Savin, \& Famish, 1991). Therefore, reading comprehension is a big issue around the world. TOEIC (2016) reports that Chilean, Taiwanese, Peruvian, Brazilian, and Japanese people have the highest rate and emphasize that reading is their most used skill. However, Program for International Student Assessment (PISA, 2012) reported that of a group of 64 assessed countries in 2012, 32 improved their reading performance; nevertheless, 22 did not have any change, and 10 deteriorated their reading performance (The Guardian, 2016). Common European Framework of Reference (2001) includes in receptive skills the visual reception or reading which deals with material that the language user receives and processes as an input of his or her learning of the target language process. In contrast, in many countries around the world, the interest in reading has declined because of media and the development of the amusement industry which has displaced reading books as a source of information and leisure (Kamalova \& Koletvinova, 2016).

At Unidad Educativa "Riobamba", there is an important report which states that levels of reading comprehension are under the $50 \%$ of performance. It is alarming because 378 students of third of bachillerato took "Ser Bachiller" test and the results of that exam in the linguistic section were just $51.1 \%$ of the students succeed in reading comprehension (INEVAL, 2017). Furthermore, at the beginning of the 2017-2018 academic period, the researcher has given the diagnostic test to students belonging to first year of baccalaureate and the results were deficient. Students do not read nor understand. They guess their answers according to the example provided.

Reading comprehension is a fundamental aspect of language development. However, a number of English teachers are interested in helping students to complete worksheets rather than providing reading strategies to improve comprehension (Adnyana, 2014). Fitria (2015) states that "English teachers do not use appropriate techniques or methods; therefore, it gives impact to the students and the class condition during teaching and learning process". Consequently, the teachers' role is to help students to understand what they read (Fitria, 
2015). That is the reason why the present research is interesting, important, newfangled, helpful, and feasible.

This research is interesting for teachers and students because teachers want to improve their teaching strategies and be prepared for helping students. Felder and Brent (2013) argue that cooperative learning helps to minimize unpleasant situations when students cooperatively work and maximize learning and satisfaction when they are working in groups; consequently, students and teachers have higher performance when working in teams. Therefore, the present research is interesting because teachers have valuable information to understand the use of cooperative learning in the development of reading comprehension. Hence, the current research looks for effective activities and resources which help for enhancing reading comprehension development.

Furthermore, the present work is relevant. Although the terms, reading comprehension and cooperative learning are well known in the educational field, the fusion of these two terms can be used to foster Ecuadorian teaching practices. It will help teachers because comprehension is showed by students when they can remember important aspects of the reading material, and the number of questions they can answer correctly. On the other hand, quality of comprehension is understood based on the rank to which students answer comprehension questions at inference making levels (McNamara, 2007).

Besides, the current study is feasible. This research is focused on students from Unidad Educativa "Riobamba" since they struggle with reading comprehension. Therefore, it is extremely necessary to help them to solve these problems for improving their English knowledge. This research has enough support from school authorities, parents, students, and the board of English teachers; so, this research would have a positive impact. Students have to take international exams which contain reading comprehension tasks; hence, they will succeed.

It is fundamental to describe literature review related to cooperative learning on reading comprehension in order to understand the research problem.

Johnson, Johnson, and Stanne (2000) claim cooperative learning is one of the most helpful, extended and fruitful areas of theory, research, and practice in the educational field. The methodology adopted for this research is a meta-analysis which consists of a literature review and the calculation of effect sizes in a statistical combination of results that test the same hypothesis. It also uses inferential statistics to draw conclusions about the general result of the research. This meta-analysis is centered on answering four main questions such as 1) how much investigation has been addressed on cooperative learning methods, 2) how many different cooperative learning methods can be assessed, 3) how effective each method assessed is in the best student achievement, and 4) what the features of the most effective 
cooperative learning methods are. According to the authors, 164 studies have been found which are investigating eight cooperative learning methods. Those studies showed the same number of independent effect sizes which represent significant and positive academic achievements. They compared cooperative learning with competitive learning. The results of the research show that cooperative learning promoted the greatest effect rather than competitive learning. They used academic controversy, student-team-academic-divisions, team-games tournaments, group investigation, jigsaw, and teams-assisted methods of cooperative learning, cooperative integrated reading, and composition. They conclude that cooperative learning has a greater impact than individualistic learning.

Millis (2002) states that enhancing critical thinking, promoting deep learning, encouraging self-esteem and acceptance of others, and improving interpersonal skills are the most challenging educational goals. This paper main objective is describing cooperative learning which is an instructional approach developed to enhance the challenging educational goals such as critical thinking skills, deep learning, encourage self-esteem and acceptance of others, and improve interpersonal effectiveness. The author argues that cooperative learning involves working with small groups on particular tasks which are painstakingly structured. She has developed a guide based on cooperative learning premises which discusses issues about cooperative learning classroom, activities, groups, and teams. The author concludes that teachers who understand the investigation and theory of cooperative learning and classroom management can apply them in their classes and in any curriculum. For that reason, learning is better for students who enjoy attending classes and contribute with their classmates.

Learning techniques are used to teach according to different learning conditions like students' abilities, material, and assessment. They can be practice testing which refers to practice answering quizzes about the topic of lessons. Other learning techniques can be selfexplanation, interrogation, and summarizing, identifying and marking significant content in determined text, determine new vocabulary, create mind maps, reading material various times (Henetz, 2013).

It is an instructional issue based on groups: formal and informal groups; where interpersonal skills build up social interaction through elements like face to face interaction, interdependence, accountability (Johnson \& Johnson, 1987); and collaborative skills, with techniques like jigsaw, and reciprocal questioning, and think-pair-share approach, for decision making, communication, and conflict management.

Cooperative learning promotes cooperative and collaborative work in groups. There is not just an only one form of using groups. Grouping can be distributed by the teacher to be either homogeneous or heterogeneous on their characteristics. Or students can also self- select their group forming. Those groups can be formal or informal (Garfield, 1993). 
Jacobs and Hall (2002) state that even two people can be considered as a group. Groups of three or maximum four members are the best because the group is large enough to allow students to come up with their own opinions, experiences, and even learning styles. The members of the group tend to help each other in solving problems. Additionally, even if one student is absent, the rest of the group can continue working (Millis, 2002). Groups of four are also considered as appropriated for developing big tasks. For these groups, pair work is developed first and then the two pairs interact with one another.

Slish (2005) remarks that jigsaw helps in the classroom for developing active learning. Students are engaged with the provided material. Students cooperate in groups for accomplishing the same goal. Classes are dedicated to active learning exercises. These help students to read, understand, and learn the material in a better way. In jigsaw; every single student who is member of a team is assigned a unique part of the reading material (Meng, 2010). The student reads his or her part and forms another group of students who have the same reading material. They form the group of "experts" to discuss, share and clear ideas, and master information. After that, students return to their original group in order to teach the rest of the group about what they have read. Finally, the whole group is assessed based on the reading material. Jigsaw is suitable for reading comprehension because it develops students' meta-cognitive awareness and let them learn the content when they are teaching to their peers in their groups.

Causes are reasons why something happens; on the contrary, an effect is what happens because of that cause. To recognize if the reading material has a "cause and effect" pattern, it is necessary to pay attention to the signal words and phrases that the reading material provides to the reader. Those signal words and phrases can be: 'for this reason', 'thus', 'since', 'in order to', 'as a result', 'therefore', 'consequently', 'because', 'due to', 'for this reason', and 'on account of'. It is also necessary to design graphic organizers in order to understand the 'cause and effect' pattern (Perles, 2018).

\section{Methodology}

This research is focused on the social educational model. In fact, students are motivated to learn English by working with their pairs. Hence, cooperative learning for enhancing reading comprehension is part of the students' daily life. According to the Ministry of Education students have to reach a B1.2 level in Ecuador. Therefore, it is imperative the necessity to improve reading skills. A quali-quantitative approach has been used in this research (Newman \& Benz, 1998). Hence, it focused on a social phenomenon analyzing statistics, variables, hypothesis, and, objectives. Moreover, surveys have been applied in order to get information. Finally, conclusions have been drawn (Marzano, Vegliante, \& De Angelis, 2015). 
It is essential to have direct contact with students, teachers, and authorities where the problem occurs (Boyd, 2018). The researcher carried out a direct observation to get primary data in order to determine the problem and solve it. This research is bibliographical documentary for it uses primary and secondary documents. The researcher has tested and analyzed results from bibliographical data. This is also called as archival research and is about different documents for searching data about cooperative learning for reading comprehension (Freitas, Bufrem, \& Breda, 2016).

Synchronic research was carried out during the second term of 2017-2018 academic year with first year of bachillerato of Riobamba High School in Riobamba city, Chimborazo province (Cohen, Manion, \& Morrison, 2007).

This research has contributed to the solution of a social- educational problem which is affecting students (Kowalczyk, 2003) from first year of bachillerato of Unidad Educativa "Riobamba". It also identified fundamental objectives, research questions, hypothesis, conclusions, and recommendations. This research has been supported by real facts, participants and variables; all of them were analyzed (Tatum, 2018).

The independent variable (Cooperative Learning) affects the dependent variable (Reading comprehension). There is a close relationship between them because they support each other (Kowalczyk, 2003).

For this study, the researcher has worked with ten English teachers who assist students at Unidad Educativa "Riobamba". Besides, the population includes students from first year of bachillerato in the second term of 2017-2018 academic year. Furthermore, the present work has a population of 211 students; therefore, the researcher has worked with the total of the population which is detailed in Table 1.

\begin{tabular}{lrrcc}
\multicolumn{6}{c}{ Table 1. Population and sampling } \\
\hline CLASSROOM & MEN & WOMEN & TOTAL & GROUP \\
\hline A & 4 & 26 & 30 & EXPERIMENTAL \\
B & 6 & 31 & 37 & GROUP \\
C & 7 & 28 & 35 & \\
D & 8 & 28 & 36 & CONTROL \\
E & 10 & 26 & 36 & GROUP \\
F & 9 & 28 & 37 & \\
TOTAL & 44 & 167 & 211 & \\
\hline
\end{tabular}

Source: Unidad Educativa "Riobamba" (2018)

Created by: Pilco, M. (2018) 
The data of the present research was gathered through organizing and explaining information about cooperative learning on reading comprehension (Adnyana, 2014). The data has been directed to answer the stated problem through a quasi-experimental research. For this purpose, a pre and a post-test, PET exam from Cambridge, reading section, were used. The researcher assisted 211 students in total that were divided into the experimental group which had 102 students and the control group which had 109 students who come from Unidad Educativa "Riobamba". After giving the pre-test, the researcher developed a class intervention through the use of cooperative learning for reading comprehension methodological guide for one month. After the intervention, data was collected in order to accept or reject the corresponding hypotheses. Additionally, a survey was applied to both English teachers and students. It was validated by two professionals in teaching English as a foreign language.

\section{Results}

\section{Pre- Test and Post- Test Results}

This study assisted to both control and experimental group; the former was composed by 109 learners and the latter was composed of 102 students which belonged to first year of bachillerato at Unidad Educativa "Riobamba" in the second term of 2017-2018 academic period.

Both the control group and the experimental one took the same pre-test, PET exam from Cambridge, in order to assess their reading comprehension skills. The first part of the exam aimed to evaluate their work in pairs and the second part of it was designed in order to evaluate their group work. The exam was divided into two sets. The first part had a duration of 30 minutes and the classes were divided into pairs to read a 3 short pieces of reading which had one multiple choice question each one. Additionally, the second part of the test had duration of other 30 minutes and the classes were divided into groups of 4 students to read and answer a longer piece of reading that contained 5 questions. The same structure but different readings and questions were selected for the post-test, PET exam from Cambridge. For this reason, the data analysis of the pre and post-tests were divided into two parts: the first one is the analysis of the students reading comprehension development when they worked in pairs and the second part of the analysis aimed to study the students' results when working in groups of four.

Table 2. Pre and post-tests results: pair work

\begin{tabular}{lcc}
\hline \multicolumn{3}{l}{ Pre and post test results - Experimental and Control groups: pair work } \\
\hline Category & Pre - test & Post - test \\
Experimental group: pair work & 2,04 & 4,44 \\
Control group: pair work & 1,74 & 2,93
\end{tabular}

Source: Pre and post-tests results. Experimental and control groups: pair work

Author: Pilco, M. (2018) 


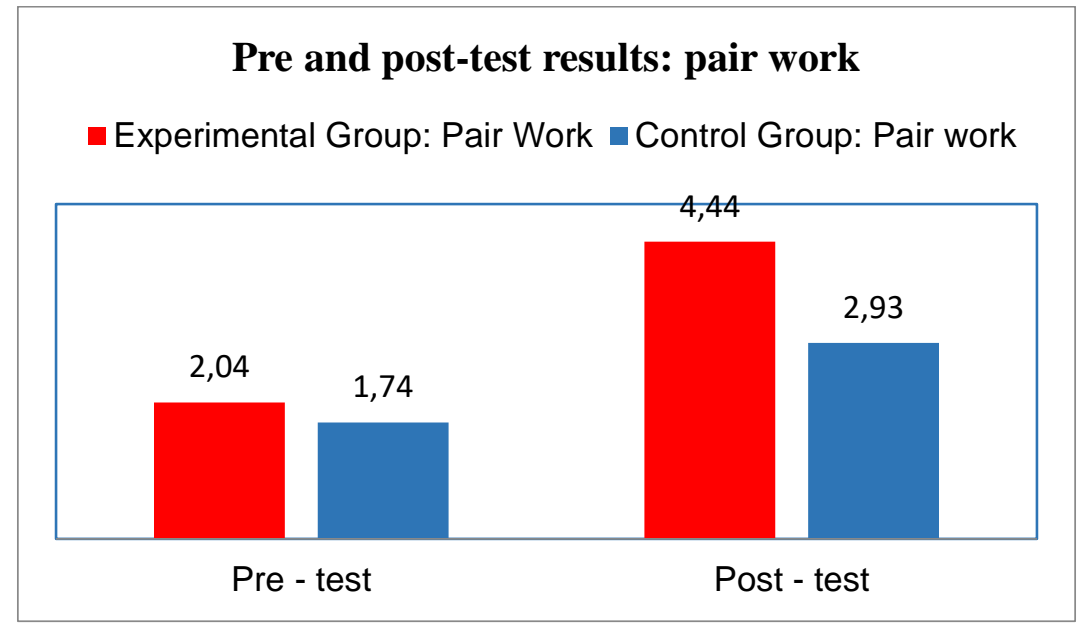

Figure 1. Pre and post-tests results: pair work

Source: Pre and post-tests results. Experimental and control groups: pair work

Author: Pilco, M. (2018)

This study aimed to prove whether the effects of cooperative learning influence on reading comprehension or not. Therefore, the alternative hypothesis aimed to prove that the effects of cooperative learning do influence on reading comprehension; on the contrary, the null hypothesis stated the effects of cooperative learning do not influence on reading comprehension.

For the hypothesis verification, SPSS statistical software was used in order to apply the Tstudent.

\section{Normal distribution test}

Table 3. Normal distribution test: experimental work

\section{EXPERIMENTAL GROUP}

Kolmogorov-Smirnov test for one data ${ }^{a}$

\begin{tabular}{ccc} 
& & PRE-TEST \\
\hline \multirow{2}{*}{ Normal parameters ${ }^{\mathrm{b}, \mathrm{c}}$} & Mean & 50 \\
& Std. Deviation & 2,040 \\
Most extreme differences & Absolute & 0,23903 \\
& Positive & 0,230 \\
& Negative & $-0,210$ \\
Test statistic & & 0,230 \\
Asip.Sig. (2 tailed) & $0,000^{\mathrm{d}}$
\end{tabular}

Source: Pre-test experimental group

Author: Pilco, M. (2018) 
Table 4. Normal distribution pre-test control group

\begin{tabular}{ccc}
\hline \multicolumn{2}{c}{ CONTROL GROUP } \\
\multicolumn{2}{c}{ Kolmogorov-Smirnov test for one data ${ }^{\mathrm{a}}$} \\
\\
\multicolumn{1}{c}{$\mathrm{N}$} & PRE-TEST \\
\hline Normal parameters ${ }^{\mathrm{b}, \mathrm{c}}$ & Mean & 54 \\
& Std. Deviation & 1,741 \\
Most extreme differences & Absolute & 0,5070 \\
& Positive & 0,228 \\
& Negative & $-0,216$ \\
Test statistic & & 0,228 \\
Fsip. Sig. (2 tailed) & $0,000^{\mathrm{d}}$ \\
\hline
\end{tabular}

Source: Pre-Test Control group

Author: Pilco, M. (2018)

P.sig $<0.05$

For the normal distribution of data as the experimental group as for the control group the Kolmogorov-Smirnov test for one data was applied.

Hence, p.sig that corresponds for these results, is 0.000 and it is less than 0.05 ; therefore, the data that comes from the experimental group and the control group are normal like as the tables above show.

These results mean that the researcher can continue with the next test which is T student for comparing population means.

T - Student test for comparing population means

Table 5. Student test. Comparing population means, pre-test

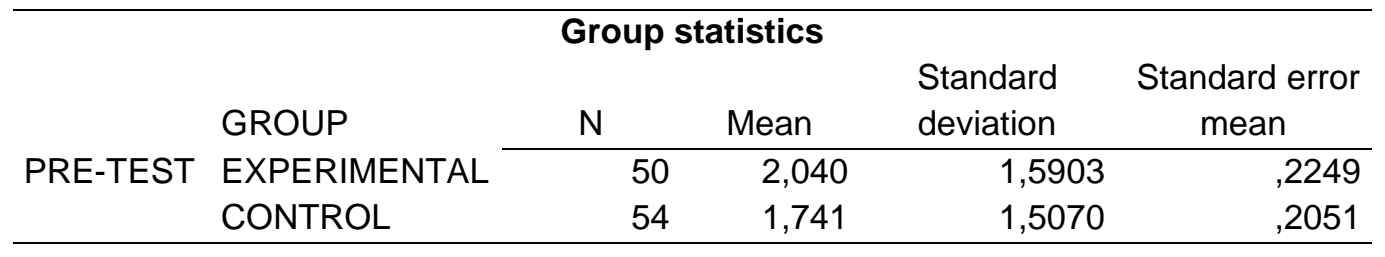

Source: T-Test. Comparing population means. Pre-test

Author: Pilco, M. (2018) 
Table 6. Levene test for equality. Pre-test

\section{Independent samples T-test}

Levene test

for equality T- test for equality of means

\begin{tabular}{|c|c|c|c|c|c|c|c|c|c|c|}
\hline & \multirow[b]{3}{*}{$F$} & \multirow[b]{3}{*}{ Sig. } & \multirow[b]{3}{*}{$\mathrm{T}$} & \multirow[b]{3}{*}{$\mathrm{gl}$} & \multirow{3}{*}{$\begin{array}{l}\text { Sig.(tw } \\
0 \\
\text { tailed) }\end{array}$} & \multirow{3}{*}{$\begin{array}{c}\text { Mean } \\
\text { difference }\end{array}$} & \multirow{3}{*}{$\begin{array}{c}\text { Standar } \\
\text { d error } \\
\text { differenc } \\
\text { e }\end{array}$} & \multirow{2}{*}{\multicolumn{2}{|c|}{$\begin{array}{c}95 \% \text { Confidence } \\
\text { interval of the } \\
\text { difference }\end{array}$}} \\
\hline & & & & & & & & & & \\
\hline & & & & & & & & & Inferior & Superior \\
\hline PRE- & Equal & 0,063 & 0,80 & 0,985 & 102 & 0,327 & 0,2993 & 0,3037 & - & 0,9017 \\
\hline \multirow[t]{5}{*}{ TEST } & variances & & 2 & & & & & & 0,3032 & \\
\hline & assumed & & & & & & & & & \\
\hline & Equal & & & 0,983 & 100,2 & 0,328 & 0,2993 & 0,3044 & - & 0,9031 \\
\hline & variances not & & & & 71 & & & & 0,3046 & \\
\hline & assummed & & & & & & & & & \\
\hline
\end{tabular}

Source: T-test. Comparing population means. Pre-test

Author: Pilco, M. (2018)

In the Levene test for equality of variances, it is clearly assumed that the Sig. is $>0.05$; in this case, it is 0.802 . Therefore, it is needed to say that equal variances are assumed because there are high differences between the two populations' variances.

Furthermore, the T-test table shows that the Sig. is 0,327 which is > 0.05; therefore, there is a difference between the mean in the control group and the mean in the experimental group. In other words, the mean of experimental group is higher than the mean of the control group in the pre-test.

\section{T- Test}

The final $\mathrm{T}$ - test aimed to verify whether there is a significant difference between the means of the control group and the experimental one in the post-test. This hypothesis is planted because the alternative hypothesis in this study refers that the effects of cooperative learning influence on reading comprehension development. Since the researcher has implemented a class intervention based on cooperative learning for improving reading comprehension, it is needed to see if the intervention has had good results or not.

\section{The hypothesis is:}

$$
\mu 1 \neq \mu 2
$$

The formula signifies that the mean in the experimental group, G1, is not the same as the mean in the control group, G2. 
Table 7. T-test. Group statistics. Post-test

\begin{tabular}{ccccc}
\hline \multicolumn{5}{c}{ Group statistics } \\
\hline GROUP & $\mathrm{N}$ & Mean & deviation & Standard error \\
POST-TEST EXPERIMENTAL & 50 & 4,440 & 1,3577 & mean \\
CONTROL & 54 & 2,926 & 1,4902 &, 2028 \\
\hline
\end{tabular}

Source: T-Test. Group statistics. Post-test

Author: Pilco, M. (2018)

Table 8. Comparing population means. Post-test

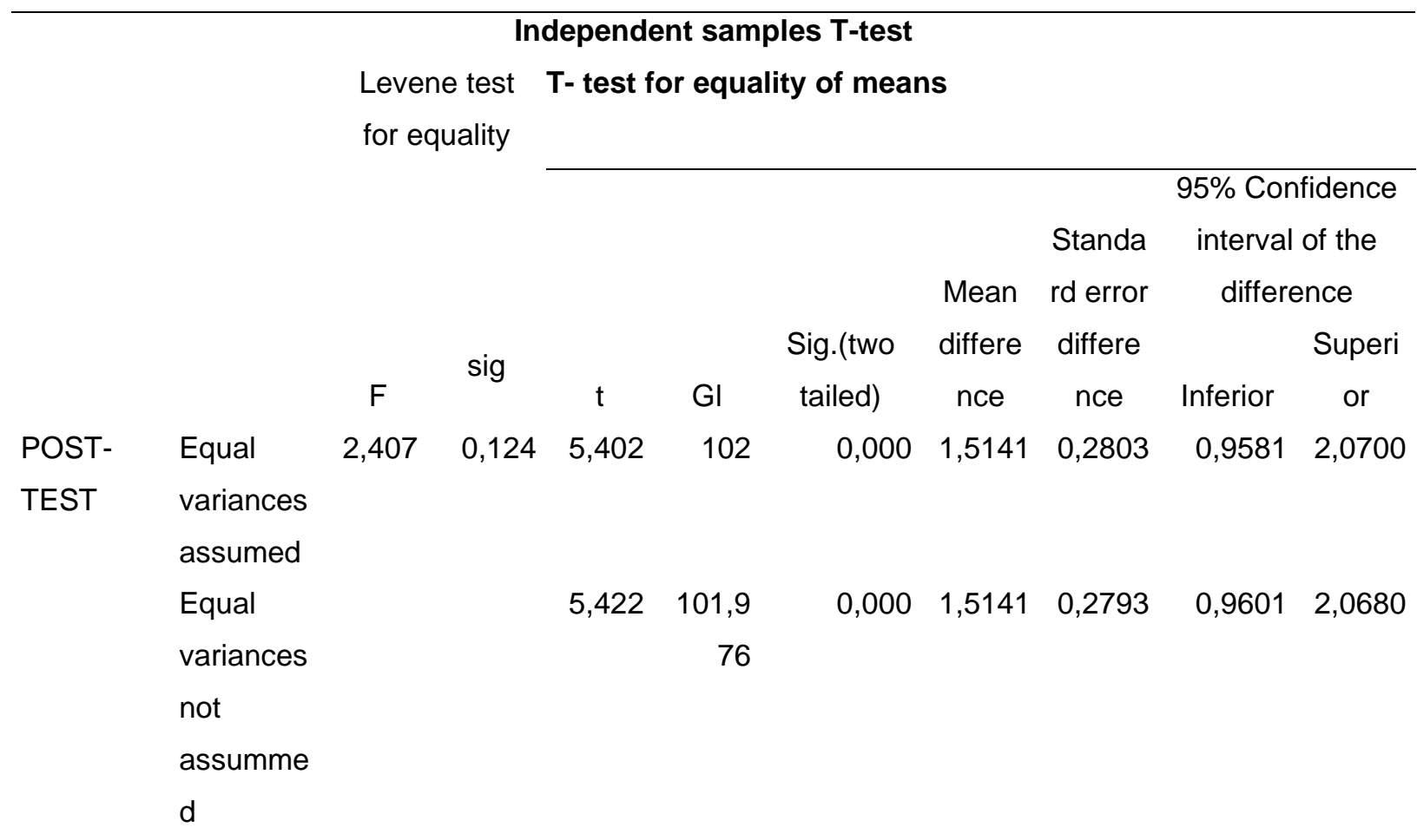

Source: Independent samples T- test. Post-test

Author: Pilco, M. (2018)

\section{Final decision}

In the Levene test for equality, it is shown that sig. is $>0.05$ that is 0.124 . It implies that the variances are statistically equal.

On the other hand with a standard of error mean of 0,1920 it is concluded that there is a high difference between the means of the $\boldsymbol{\mu} \boldsymbol{1}$ with respect to $\boldsymbol{\mu} \mathbf{2}$. G1 or experimental group had a final mean of 4.440 which is higher than the result of the $\mathrm{G} 2$ or control group that obtained a final mean of 2.926 . 
In conclusion, the alternative hypothesis is accepted and the null hypothesis is rejected. Furthermore, the researcher's intervention with the proposal "A methodological guide with cooperative learning activities for improving reading comprehension development" had a good impact in the students of first of bachillerato at Unidad Educativa "Riobamba" for the 2017-2018 academic period.

\section{Pre-test and post- test results and analysis: group work}

As it was detailed in the previous numeral, the pre- and post-tests had two sections. The first section was developed by students in pairs and the other part was performed in groups of four students. This second section had one long piece of reading with 5 multiple choice questions. The students had to 30 minutes to read, analyze, and answer the questions.

For the analysis of data, the researcher has used the same scheme that in the first part. It means that SPSS statistical software was used for obtaining the normality T- test, equality of variances, contrast and compare of the pre-and post-test results through $\mathrm{T}$ - student, and final decision.

Data obtained for the group work

Table 9. Group work. General results

\begin{tabular}{lcccc}
\hline & \multicolumn{3}{c}{ GROUP WORK } & \multicolumn{2}{c}{ CONTROL GROUP } \\
& EXPERIMENTAL GROUP & \multicolumn{2}{c}{ CONTR } \\
GROUP 1 & PRE-TEST & POST-TEST & PRE-TEST & POST-TEST \\
GROUP 2 & 2 & 6 & 2 & 4 \\
GROUP 3 & 4 & 6 & 4 & 2 \\
GROUP 4 & 4 & 2 & 0 & 4 \\
GROUP 5 & 6 & 10 & 2 & 0 \\
GROUP 6 & 2 & 8 & 2 & 2 \\
GROUP 7 & 0 & 8 & 6 & 6 \\
GROUP 8 & 2 & 8 & 0 & 0 \\
GROUP 9 & 2 & 4 & 0 & 2 \\
GROUP 10 & 2 & 10 & 4 & 2 \\
GROUP 11 & 4 & 6 & 2 & 4 \\
GROUP 12 & 2 & 10 & 2 & 2 \\
GROUP 13 & 2 & 10 & 4 & 4 \\
GROUP 14 & 4 & 8 & 0 & 2 \\
GROUP 15 & 0 & 6 & 0 & 2 \\
GROUP 16 & 4 & 8 & 0 & 4 \\
GROUP 17 & 4 & 10 & 4 & 0 \\
\hline
\end{tabular}




\begin{tabular}{ccccc}
\hline \hline GROUP 18 & 0 & 8 & 6 & 4 \\
GROUP 19 & 0 & 6 & 0 & 2 \\
GROUP 20 & 2 & 6 & 6 & 2 \\
GROUP 21 & 4 & 6 & 0 & 0 \\
GROUP 22 & 4 & 2 & 0 & 2 \\
GROUP 23 & 2 & 10 & 0 & 6 \\
GROUP 24 & 4 & 6 & 4 & 4 \\
GROUP 25 & 2 & 8 & 4 & 0 \\
Average & $\mathbf{2 . 4 8}$ & $\mathbf{7 . 1 2}$ & $\mathbf{2 . 1 6}$ & $\mathbf{2 . 5 6}$ \\
\hline
\end{tabular}

Source: General results. Group work

Author: Pilco, M. (2018)

\section{Normality distribution test}

To prove the hypothesis of data normality, the Kolmogorov-Smirnov test was used because this test helps to prove that the sample data come from a normal distribution.

In SPSS statistical software the following steps were followed: First, the researcher had to segment data, then she had to apply KS T-test for one sample, and finally the analysis of F.sip. Significant. As the table above shows, the F. significant is < 0.05 ; therefore, data of the experimental group come from a normal distribution.

Table 10. Normality T-test. Experimental group work

\begin{tabular}{|c|c|c|}
\hline \multicolumn{3}{|c|}{ EXPERIMENTAL GROUP } \\
\hline \multicolumn{3}{|c|}{ Kolmogorov-Smirnov test for one data ${ }^{a}$} \\
\hline \multirow{2}{*}{\multicolumn{2}{|c|}{$\mathrm{N}$}} & Pre-test \\
\hline & & 25 \\
\hline \multirow[t]{2}{*}{ Normal parameters ${ }^{b, c}$} & Mean & 2,48 \\
\hline & Std. Deviation & 1,661 \\
\hline \multirow[t]{3}{*}{ Most extreme difference } & Absolute & 0,220 \\
\hline & Positive & 0,214 \\
\hline & Negative & $-0,220$ \\
\hline \multicolumn{2}{|c|}{ Test statistic } & 0,220 \\
\hline \multicolumn{2}{|c|}{ Fsip. Sig. (2 tailed) } & $0,003^{d}$ \\
\hline
\end{tabular}

Source: Pre -test results. Experimental group: group work

Author: Pilco, M. (2018) 
Table 11. Normality test group work. Control group

\begin{tabular}{ccc}
\hline \multicolumn{3}{c}{ CONTROL GROUP } \\
\multicolumn{3}{c}{ Kolmogorov-Smirnov test for one data } \\
\hline \multirow{2}{*}{$N$} & & PRE-TEST \\
Normal parameters ${ }^{\mathrm{b}, \mathrm{c}}$ & Mean & 25 \\
& Std. Deviation & 2,16 \\
Most extreme differences & Absolute & 0,154 \\
& Positive & 0,242 \\
& Negative & $-0,164$ \\
& Test statistic & 0,242 \\
Fsip. Sig. (2 tailed) & $0,001^{\mathrm{d}}$ \\
\hline
\end{tabular}

Source: Pre -Test results. Experimental group: group work normality test Author: Pilco, M. (2018)

In the same way, the Kolmogorov-Smirnov test for one data was applied for the control group, and the result is that data come from a normal distribution because the F.sip.sig is < 0.05 .

The next step is to apply the T-student in order to compare the population means.

\section{T- Student}

This test is used for comparing the assumption of equality of variance. For doing it, the Levene test for equality was applied.

Table 12. Group work: assumption of equality of variances test

\begin{tabular}{llrrrr}
\hline & & & Group Statistics & & \\
& Group & N & Mean & $\begin{array}{c}\text { Standard } \\
\text { deviation }\end{array}$ & \multicolumn{2}{c}{$\begin{array}{c}\text { Standard error } \\
\text { difference }\end{array}$} \\
\hline Pre-test & Experimental & 25 & 2,48 & 1,661 &, 332 \\
& Control & 25 & 2,16 & 2,154 &, 431 \\
\hline
\end{tabular}

Source: Pre -test results. Experimental and control group: Group work: assumption of equality of variances test

Author: Pilco, M. (2018) 
Table 13. Levene test for equality of variances. Group work

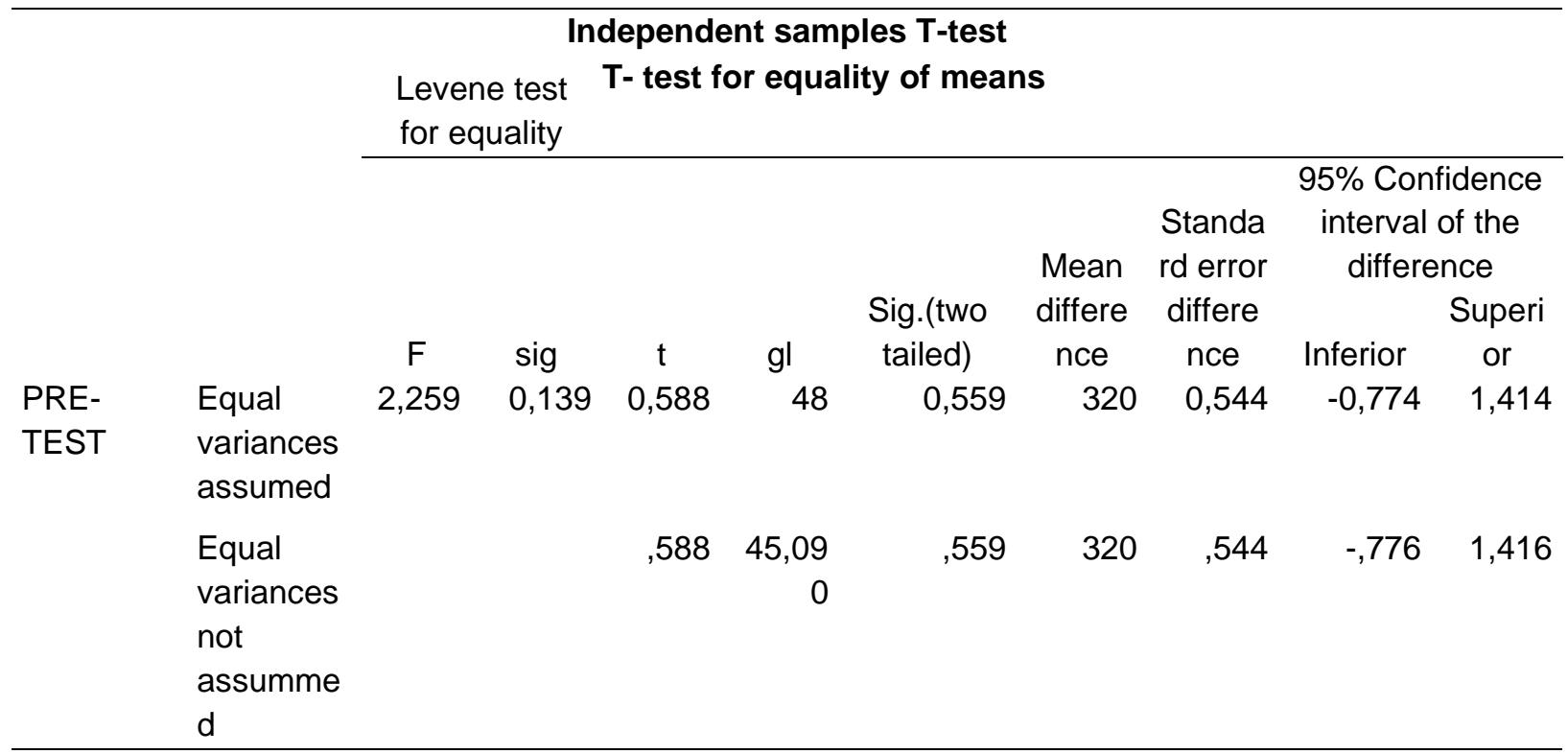

Source: T-Test. Group statistics. Levene test for equality of variances. Pre-test; group work Author: Pilco, M. (2018)

As the table above shows, in the pre-test the sig. is $>0.05$; being $0.139>0,05$; therefore it is concluded that the Levene test of equality shows that there is equality of variances.

Besides, the researcher has compared the means in the two groups. It is noticed that Sig. in the table above is 0,559 which is $>0.05$; therefore it is needed to say there are differences between the pre-test of the experimental group and the pre-test in the control group. However, this difference is not too significant.

\section{T- TEST: group work. Post- test}

Similarly to the pair group work analysis, the researcher has verified whether there is a significant difference between the means of the control group and the experimental one in the post-test. This hypothesis is showed because the H1 in this study makes the assumption that the effects of cooperative learning influence on reading comprehension development. The hypothesis is:

$$
\begin{gathered}
\boldsymbol{\mu} \mathbf{1} \neq \boldsymbol{\mu} \mathbf{2} \\
\mathbf{G} \mathbf{1} \neq \mathrm{G} \mathbf{2}
\end{gathered}
$$

This formula implies that the mean in the experimental group, G1, is not the same as the mean in the control group, G2. Therefore, it is clearly showed that the mean in the 
experimental group for the post-test is highly different from the mean in the post-test of the control group.

Table 14. T-test. Group statistics. Post-test group work

\begin{tabular}{|c|c|c|c|c|c|}
\hline \multicolumn{6}{|c|}{ Group statistics } \\
\hline & & & & Standard & Standard error \\
\hline & GROUP & $\mathrm{N}$ & Mean & deviation & mean \\
\hline \multirow[t]{2}{*}{ POST-TEST } & EXPERIMENTAL & 25 & 7,12 & 2,315 & 0,463 \\
\hline & CONTROL & 25 & 2,56 & 1,781 & 0,356 \\
\hline
\end{tabular}

Source: T-Test. Group statistics. Post-test; group work

Author: Pilco, M. (2018)

Table 15. Comparing population means. Post-test- Group work Independent samples T-test Levene test T- test for equality of means for equality

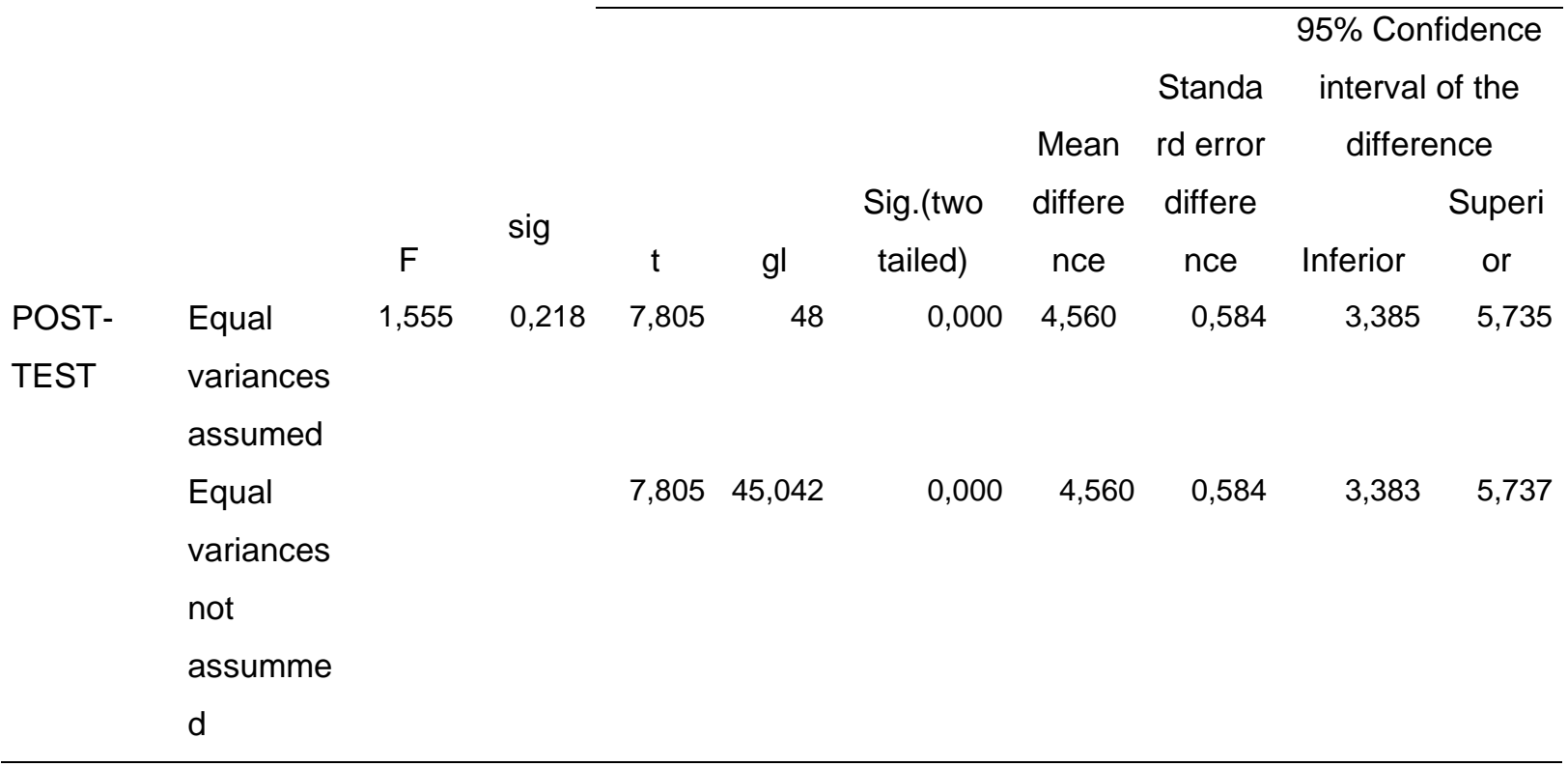

Source: Independent samples T- test. Post-test - Group work

Author: Pilco, M. (2018)

In the table above, the sig. is $<0,05$; therefore, there are significant differences between the post- test in the $\mathrm{G} 1$ and $\mathrm{G} 2$ being the results in the experimental group higher than the results of the post-test of the control group.

Furthermore, it is needed to analyze if the results of the pre-test and the post-test in the experimental group are different. 
Therefore, the T- test is applied:

Table 16. Paired sample T-test. Experimental group

\begin{tabular}{lcccccc}
\hline \multicolumn{4}{c}{ Paired sample statistics experimental group } \\
& & Mean & N & & $\begin{array}{c}\text { Standard } \\
\text { deviation }\end{array}$ & $\begin{array}{c}\text { Standard error } \\
\text { difference }\end{array}$ \\
\cline { 6 - 7 } Par 1 & Pre- test & 2,48 & 25 & & 1,661 & 0,332 \\
& Post-test & 7,12 & 25 & & 2,315 & 0,463 \\
\hline
\end{tabular}

Source: Independent samples T- test. Post-test - Group work

Author: Pilco, M. (2018)

In the table below, it is showed that the sig. is $>0.005$; hence, there is big difference between the pre-test and the post test results.

Table 17. Correlation of paired samples. Pre and post-tests. Experimental group

Correlation of paired samples

Pre- and Post-tests - Experimental group

\begin{tabular}{|c|c|c|c|c|}
\hline & & $\mathrm{N}$ & Correlation & Sig. \\
\hline Par 1 & Pre-Test \& Post-Test & 25 & $-0,102$ & 0,627 \\
\hline
\end{tabular}

Source: paired samples T- test. Post-test - Group work

Author: Pilco, M. (2018)

Table 18. Pair sample test

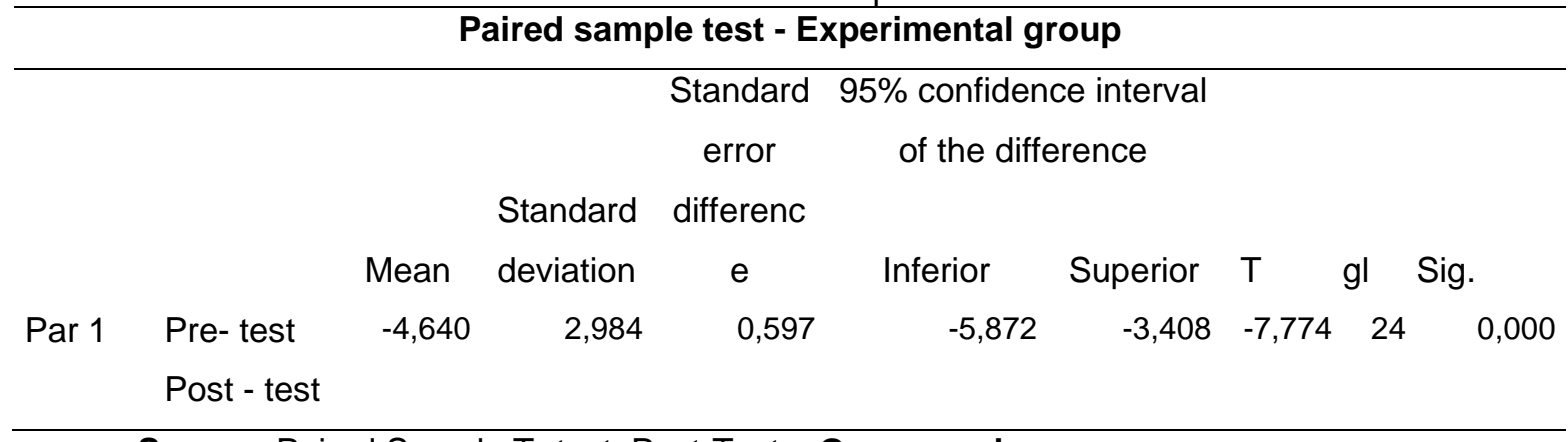

Source: Paired Sample T- test. Post-Test - Group work

Author: Pilco, M. (2018)

In the table above, there is evidenced that the Sig. is $<0,05$; therefore, there is a high difference between the pre-test and the post test of the Experimental group.

\section{Final decision}

After performing the teacher's intervention, the results indicate that there is a significant difference between the pre and post-test in the experimental group. Therefore, the application of cooperative learning for reading comprehension gave good results in the experimental group as the figure below shows: 


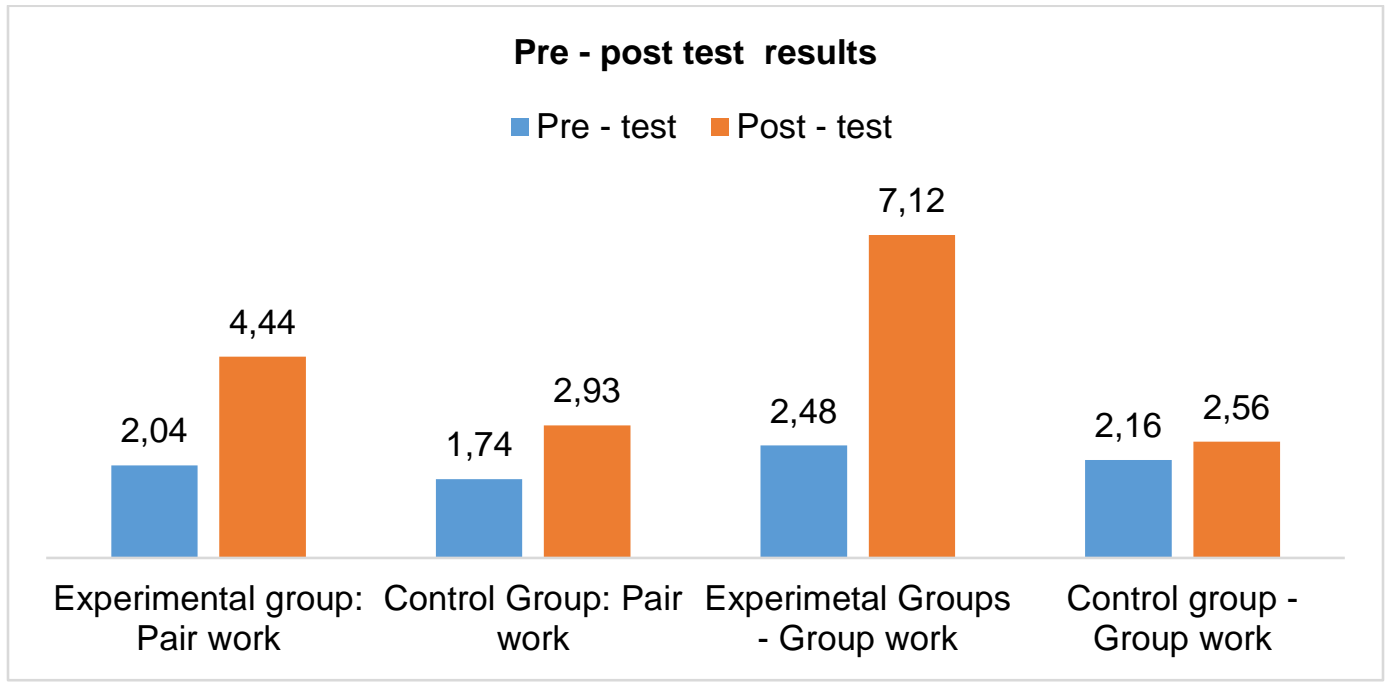

Figure 1. Final results

Source: Final results

Author: Pilco, M. (2018)

Besides, it is also evident that students' performance is higher in the group work than the pair work.

\section{Conclusions}

- In accordance with T-student test, it has summed up that cooperative learning had contributed to improve reading comprehension development to students of first year of bachillerato at Unidad Educativa "Riobamba" in the 2017-2018 academic year. In other words, the impact of cooperative learning on reading comprehension was high with positive effects on students' development.

- Most helpful cooperative learning strategies were identified in order to enhance the students' reading comprehension. Those cooperative learning strategies were identified and used in the proposal for better development of the students such as jig-saw, reciprocal questioning, cooperative reading role cards, think-pair share, number heads together, and PMI which let both students and teacher develop positive attitudes towards group cooperation. Students showed lots of interest for learning and improving their reading comprehension skills; therefore, their interest encourages for keep going this research project. Students showed their positive attitude while working in pairs and in groups as well. This motivating attitude elicited the results in the pre and post-tests results. Students' cooperation was crucial for the successful accomplishment of goals.

- There were positive effects on reading comprehension of students who attend to classes with the use of cooperative learning compared with students who attend regular English classes. After different reading strategies were identified which are related to cooperative learning, students have worked in both pairs and small groups with strategies such as identifying the main idea and supporting details, summarizing, cause and effect, sequence, making predictions, drawing conclusions, making inferences, compare and contrast, fact or opinion, and identifying authors' purpose. And the intervention was 
developed in the experimental group. The teacher has developed her intervention in steps: before, during, and after reading. Those steps were managed with cooperative learning approach with good results because in the pre-test students of the experimental group had a media of 1,66 and in the post-test they obtained 7,12 with $95 \%$ of confidence. On the other hand, the control group obtained 1,74 in the pre-test and 2.93 in the post-test. These results clearly show that the impact of cooperative learning is high with respect to students' reading comprehension.

\section{Reference Bibliography}

Boyd, N. (2018). Study.com. Retrieved May 24, 2018, from How Observational \& Field Research Are Used to Collect Data: https://study.com/academy/lesson/howobservational-field-research-are-used-to-collect-data.html

L., Manion, L., \& Morrison, K. (2007). Research Methods in Education. New York: Routledge Taylor \& Francis Group. Retrieved from https://www.researchgate.net/publication/44824604_Research_Methods_in_Educati on

Felder, R., \& Brent, R. (2013). Cooperative Learning. Cary: Education Designs, Inc. Retrieved from http://www4.ncsu.edu/unity/lockers/users/f/felder/public/Papers/CLChapter.pdf

Garfield, J. (1993). Teaching Statistics Using Small-Group Cooperative Learning. Journal of Statistics Education , 1-4. Retrieved from https://www.tandfonline.com/doi/full/10.1080/10691898.1993.11910455

Henetz, T. (2013, May 15). Stanford Teaching commons. Retrieved April 20, 2018, from Teaching techniques: https://teachingcommons.stanford.edu/teaching-talk/learningtechniques-research-reveals-dos-and-don\%E2\%80\%99ts

INEVAL. (2017). Instituto Nacional de Evaluación Educativa. Retrieved October 7, 2017, from http://www.evaluacion.gob.ec/

Jacobs, G., \& Hall, S. (2002). Implementing Cooperative Learning. In J. Richards, \& W. Renardya, Methodology in Language Teaching (pp. 52-59). Cambridge: Cambridge University Press.

Johnson, D., Johnson, R., \& Stanne, M. (2000). Cooperative Learning Methods: A MetaAnalysis. Mineapolis: University of Minesota.Retrieved from https://www.researchgate.net/profile/David_Johnson50/publication/220040324_Co operative_learning_methods_A_meta- 
analysis/links/00b4952b39d258145c000000/Cooperative-learning-methods-Ameta-analysis.pdf

Kamalova, L., \& Koletvinova, N. (2016). The Problem of Reading and Reading Culture Improvement of Students Bachelors of Elementary Education in Modern High Institution. Retrieved from International Journal of Environmental \& Science Education,:

https://www.google.com.ec/search?q=reading+problems+around+the+world\&oq=re ading+problems+around+the+world \&aqs=chrome..69i57.7736j0j7\&sourceid=chro me\&ie $=$ UTF- 8

Kowalczyk, D. (2003). Study.com. Retrieved February 2, 2018, from Quasi-Experimental Designs: Definition, Characteristics, Types \& Examples: https://study.com/academy/lesson/quasi-experimental-designs-definitioncharacteristics-types-examples.html

Marzano, A., Vegliante, R., \& De Angelis, M. (2015). Quali-Quantitative Approach In Educational Research. Madrid: University of Salermo. Retrieved from https://www.researchgate.net/publication/280521706_QUALIQUANTITATIVE_APPROACH_IN_EDUCATIONAL_RESEARCH

Marzbana, A., \& Alinejadb, F. (2014). The Effect of Cooperative Learning on Reading Comprehension. Iran: ScienceDirect. Retrieved from https://www.sciencedirect.com/science/article/pii/S1877042814008519

McNamara, D. (2007). Reading Comprehension Strategies. New York: Lawrence Erlbaum Associates.

Meng, J. (2010). Jigsaw Cooperative Learning in English Reading. Retrieved from Journal of Language Teaching and Research: http://www.academypublication.com/issues/past/jltr/vol01/04/29.pdf

Millis, B. (2002). Idea Paper \#38. Retrieved October 11, 2017, from Enhancing Learning and More! Through Cooperative Learning: http://www.ideaedu.org/Portals/0/Uploads/Documents/IDEA\%20Papers/IDEA\%20 Papers/IDEA_Paper_38.pdf

Perles, K. (2018). Bright Hub Education. Retrieved October 24, 2017, from http://www.brighthubeducation.com/lesson-plans-grades-3-5/43463-teaching-causeand-effect/

Slish, D. (2005). Assessment of the use of the Jigsaw Method and Active Learning in Nonmajors, Introductory Biology. Ney York: Millikin University. Retrieved from https://eric.ed.gov/?id=EJ876525 
Stevens, R., Savin, R., \& Famish, A. (1991). The Effects of Cooperative Learning and Direct Instruction in Reading Comprehension Strategies on Main Idea Identification . Maryland: Journal of Educational Psychology.

\section{Para citar el artículo indexado.}

emache Carrillo, N., Pilco Labre, M., \& Yanez Valle, V. (2019). The effects of cooperative learning on reading comprehension. Explorador Digital, 3(3.1), 143-163.

https://doi.org/10.33262/exploradordigital.v3i3.1.875

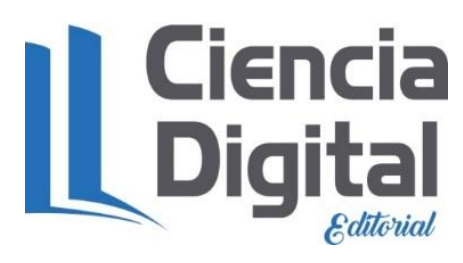

El artículo que se publica es de exclusiva responsabilidad de los autores y no necesariamente reflejan el pensamiento de la Revista Explorador Digital.

El articulo queda en propiedad de la revista y, por tanto, su publicación parcial y/o total en otro medio tiene que ser autorizado por el director o editor de la Revista Explorador

\section{Digital.}
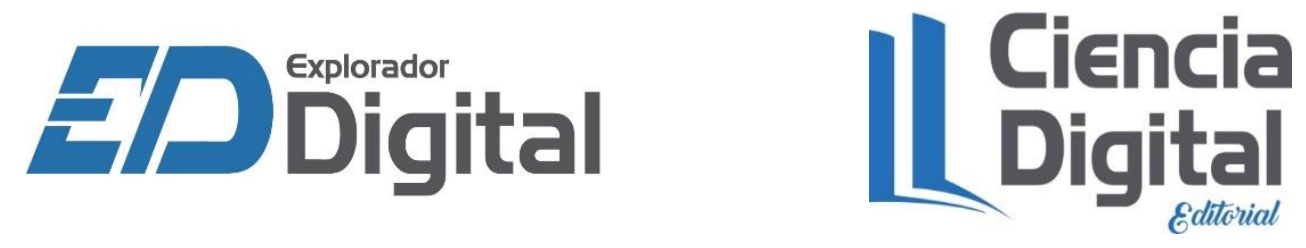